\title{
PENANAMAN KARAKTER KERJA KELAUTAN DAN PERIKANAN DI SMKN 1 SANDEN, BANTUL YOGYAKARTA
}

\author{
Gustiana Fitra Wahyuna \\ SMK Negeri 1 Pulau Laut Barat Kota Baru Kalimantan Selatan \\ gustianafw@yahoo.com
}

\begin{abstract}
Abstrak
Penelitian ini bertujuan untuk mengungkap penanaman karakter kerja kelautan dan perikanan yang diterapkan di SMKN 1 Sanden, Bantul Yogyakarta. Penelitian ini menggunakan metode penelitian kualitatif. Subjek penelitian meliputi warga sekolah, kegiatan-kegiatan yang dilaksanakan serta keadaan sekolah secara umum. Pengumpulan data dilakukan dengan metode observasi, partisipan, wawancara, dan dokumentasi. Keabsahan data dilakukan dengan triangulasi, ketekunan, dan diskusi dengan teman sejawat. Analisis data dilakukan dengan reduksi data, penyajian data, dan penarikan kesimpulan. Temuan penelitian ini diantaranya yaitu konsep yang dipakai adalah memperbaiki kebiasaan siswa yang kurang baik dan membiasakan yang baik dengan menanamkan karakter-karakter yang berhubungan dengan kebutuhan dunia kerja. Implementasinya dilakukan dengan cara inkulkasi, pembiasaan, keteladanan, dan fasilitasi. Wahana yang digunakan dalam penanaman karakter kerja tersebut yaitu kegiatan ekstrakurikuler, kokurikuler dan intrakurikuler. Hasil penanaman karakter kerja kelautan dan perikanan ini telah memenuhi target dalam kebutuhan dunia kerja walau belum 100\%.
\end{abstract}

Kata kunci: penanaman, karakter kerja, kelautan dan perikanan

\section{INCULCATING THE CHARACTER OF THE WORK ON MARINE AND FISHERIES IN SMKN 1 SANDEN BANTUL YOGYAKARTA.}

\author{
Gustiana Fitra Wahyuna \\ SMK Negeri 1 Pulau Laut Barat Kota Baru Kalimantan Selatan \\ gustianafw@yahoo.com
}

\begin{abstract}
This study is aimed to reveal the inculcation of the character of the work on marine and fisheries in SMKN 1 Sanden, Bantul. This study used the qualitative research method. The subjects of this research included school community, the activities carried out and school condition. The data were collected through observation, participans, interviews, and documentation. The validity of the data was done by triangulation, diligence and discussions with colleagues. The analysis of the data used the interactive analysis consisting of data reduction, data presentation, and conclusion. The findings of this study include that the concept used is to improve students poor habits and establish related to the needs of thejob market. Its implementation is done by inculcation, habituation, exemplary, and facilitation. The activities used in the cultivation of the character include extracurricular, intracurricular and cocurricular activities. The results of this work of the inculcating of character of marine and fisheries has met the target even although not $100 \%$.
\end{abstract}

Keywords: investment, working character, marine and fisheries 


\section{PENDAHULUAN}

Pemanfaatan dan pengembangan sumber daya manusia perlu diselenggarakan secara menyeluruh, terarah dan terpadu diberbagai bidang, terutama pada pendidikan dan latihan tenaga kejuruan. Pendidikan menengah kejuruan mengutamakan penyiapan siswa untuk memasuki lapangan kerja serta mengembangkan sikap profesional. Pendidikan kejuruan merupakan upaya mewujudkan peserta didik menjadi manusia produktif, untuk mengisi kebutuhan terhadap peranan-peranan yang berkaitan dengan peningkatan nilai tambah ekonomi masyarakat.

Pendidikan menengah kejuruan dikelompokkan dalam bidang kejuruan didasarkan pada perkembangan ilmu pengetahuan, teknologi, dan/atau seni, dunia industri/dunia usaha, ketenagakerjaan baik secara nasional, regional maupun global, kecuali untuk program kejuruan yang terkait dengan upaya-upaya pelestarian warisan budaya. Kemudian bidang-bidang tersebut dibagi lagi dalam program-program keahlian. Saat ini jenis keahlian (program keahlian) yang sudah dikembangkan sekolah menengah kejuruan diseluruh Indonesia terdapat 115 program keahlian. Salah satu bidang kejuruan tersebut adalah kelautan dan perikanan. Sektor kelautan dan perikanan merupakan salah satu sektor andalan dalam pembangunan yang dapat dioptimalkan pengelolaannya untuk mendatangkan devisa. Pengembangan sektor ini adalah suatu langkah yang tepat mengingat wilayah negara Indonesia hampir $70 \%$ wilayahnya merupakan perairan.

Untuk menghasilkan alumni-alumni yang handal, SMK Kelautan dan Perikanan biasanya menerapkan sistem pembentukan karakter siswa yang intensitasnya melebihi sekolah-sekolah lain. Hal ini karena dunia kerja kelautan dan perikanan membutuhkan tenaga-tenaga kerja yang memiliki keberanian, kedisiplinan, konsentrasi, tanggung jawab, serta kemampuan kerjasama yang tinggi yaitu disesuaikan dengan kondisi pekerjaan.

Penanaman karakter kerja bagi siswa SMK merupakan upaya penting dalam menghasilkan lulusan yang mampu bersaing dan berhasil dalam pekerjaannya. Oleh karena itu diperlukan kajian model pengembangan karakter kerja untuk kesiapan kerja. Siswa SMK harus dipersiapkan untuk menghadapi real job yang ada di dunia usaha dan industri.
Departemen tenaga kerja Amerika Serikat melaporkan tentang apa yang dibutuhkan dunia kerja dari sekolah, mereka memperingatkan bahwa siswa harus mengembangkan satu set dasar keterampilan dan kompetensi seperti keterampilan interpersonal, tanggung jawab individu, harga diri, keramahan, manajemen mandiri, dan integritas. (Character Education Partnership, 2012 diakses tanggal 10 oktober 2012 dari http://www.freedomforum.org/publications/first/findingcommonground/B13.Ch aracterEd.pdf). Pernyataan tersebut telah menjelaskan betapa pentingnya pemantapan karakter bagi siswa untuk persiapan mereka dalam memasuki dunia kerja nantinya.

Pentingnya pendidikan karakter terhadap pembentukan karakter kerja ini didukung oleh pendapat Daniel Goleman (2001: 274) tentang keberhasilan seseorang di masyarakat, ternyata $80 \%$ dipengaruhi oleh kecerdasan emosi, dan hanya $20 \%$ ditentukan oleh kecerdasan otak (IQ). Anak-anak yang mempunyai masalah dalam kecerdasan emosinya, akan mengalami kesulitan belajar, bergaul dan tidak dapat mengontrol emosinya. Anak-anak yang bermasalah ini sudah dapat dilihat sejak usia pra-sekolah, dan kalau tidak ditangani akan terbawa sampai usia dewasa.

Pernyataan tersebut didukung oleh National Association of College and Employe (NACE) yang berbasis di Amerika Serikat yang menyatakan bahwa di dunia kerja, keterampilan wirausaha (entrepreneur) ternyata tidak menjadi alasan utama seseorang diterima dalam dunia kerja. Begitu juga prestasi akademik yang diukur melalui Indeks Prestasi Kumulatif (IPK). Akan tetapi kemampuan berkomunikasi, kejujuran (integritas), dan kemampuan bekerjasama justru yang paling penting. Urutan teratas adalah kemampuan berkomunikasi, kejujuran, kemampuan kerja sama, kemampuan interpersonal, dan beretika. Sementara keterampilan wirausaha masuk nomor 20 dan IPK masuk urutan 17 (Suwarno, 2012 dari www.umk.ac.id/index.php?...di-dunia-kerja-karakter-lebih-utama-ket diakses tanggal 12 Desember 2012).

Pendidikan karakter telah dituangkan dalam UU No 20 Tahun 2003 Tentang Sistem Pendidikan Nasional pada Pasal 3, yang menyebutkan bahwa pendidikan nasional berfungsi mengembangkan kemampuan dan membentuk karakter serta peradaban bangsa 
yang bermartabat dalam rangka mencerdaskan kehidupan bangsa.

Bohlin (2005: 159) "Character is distinctive mark of our person; the combination of these distinguishing qualities that make us who we are. Character is deeper than appearance and reputation and constitutes more than our personality or temperament. Character is something we build, something we can call our own because we are free to modify our habits and have the power to choose our attitude and dispositions". Karakter adalah tanda pembeda kita; kombinasi kualitas pembeda yang membuat siapa kita. Karakter itu lebih dalam dari penampilan dan reputasi, dan merupakan lebih daripada kepribadian atau temperamen kita. Karakter adalah sesuatu yang kita bangun, sesuatu yang bisa kita sebut sebagai diri sendiri karena kita bebas untuk memodifikasi kebiasaan dan memiliki kekuatan untuk memilih sikap dan disposisi kita.

Menurut Sumaryanto (2011: 30) yaitu karakter atau watak merupakan perpaduan dari segala tabiat manusia yang bersifat tetap sehingga menjadi "tanda" yang khusus untuk membedakan orang yang satu dengan lain. Hal ini senada dengan pendapat Joel Kuperman (Almusanna, 2010: 247) yaitu "Character is instrument for making and graving, impress, stamp, distinctive mark, distinctive nature" atau bisa berarti karakter adalah alat untuk membuat dan mengukir, kesan, cap, tanda pembeda, atau sifat khas.

Dharma Kesuma, dkk (2011: 5) mendefinisikan bahwa pendidikan karakter adalah pembelajaran yang mengarah pada penguatan dan pengembangan perilaku anak secara utuh yang didasarkan pada suatu nilai tertentu yang dirujuk oleh sekolah. Sedangkan Doni Koesoema (2007: 162) berpendapat bahwa pendidikan karakter pada hakikatnya adalah sebuah perjuangan bagi setiap individu untuk menghayati kebebasannya dalam relasi mereka dengan orang lain dan lingkungannya, sehingga ia dapat semakin mengukuhkan dirinya sebagai pribadi yang unik dan khas, dan memiliki integritas moral yang dapat dipertanggungjawabkan.

Menurut Ridloudin (Diakses pada tanggal 12 desember 2011 dari www.kkp.go.id/.../kepala-badan-pengembangan-sdm-kelautan-perikanan-membuka-secara-resmidik...), Kepala Badan Pengembangan SDM Kelautan dan Perikanan mengharapkan SDM
Kelautan Perikanan harus memiliki etos kerja yang produktif, terampil, kreatif, disiplin, memiliki mental yang baik, bersih, berwibawa, netral dan profesional dalam menjalankan tugas pokok dan fungsinya.

Karakter kerja memberi pengertian sebagai nilai-nilai dasar kerja yang merupakan saripati kualitas rohaniah kerja seseorang yang dimensi-dimensinya meliputi intrapersonal dan interpersonal kerja. (Slamet P.H., 2011: 412-413). Menurut Rompas, (2009: 3) Kelautan adalah hal-hal yang berhubungan dengan kegiatan di laut yang meliputi dasar laut dan tanah di bawahnya, badan air, landas kontinen termasuk sumber kekayaan alam yang terkandung di dalamnya, kegiatan di permukaan laut, dan ruang atasnya. Batasan kelautan ditinjau dari definisi ruang, maka wilayah kelautan ada 6 ruang yaitu: ruang udara atau dirgantara; permukaan air (surface layer); kolom air; dasar laut; bawah tanah dasar laut serta pesisir dan daratan.

Menurut undang-undang nomor 45 tahun 2009, perikanan adalah semua kegiatan yang berhubungan dengan pengelolaan dan pemanfaatan sumber daya ikan dan lingkungannya mulai dari praproduksi, produksi, pengolahan sampai dengan pemasaran yang dilaksanakan dalam suatu sistem bisnis perikanan. Karakter kerja kelautan dan perikanan dapat diartikan sebagai sebagai suatu sifat, ciri-ciri atau karakteristik pekerjaan dalam bidang kelautan dan perikanan atau dapat pula diartikan sebagai karakter-karakter yang diperlukan dalam lingkungan pekerjaan khususnya bidang kelautan dan perikanan.

SMKN 1 Sanden adalah salah satu SMK Kelautan dan Perikanan yang telah sejak lama menerapkan penanaman karakter kerja kelautan dan perikanan. Menurut data dan informasi yang didapatkan, karakter siswa yang terbentuk sangat disukai oleh pasar kerja terutama dari luar negeri. Untuk itulah penelitian ini dilakukan untuk melihat lebih jauh bagaimanakah bentuk penanaman tersebut.

\section{METODE}

Penelitian ini menggunakan metode penelitian kualitatif. Fokus penelitian berkaitan langsung dengan penanaman karakter kerja kelautan dan perikanan. Sedangkan subjek penelitiannya meliputi kepala sekolah, 
wakil kepala sekolah bidang kurikulum, wakil kepala sekolah bidang kesiswaan, guru, pamong dan siswa. Pemilihan subjek penelitian ini berdasarkan metode purposive sampling. Metode ini digunakan dengan anggapan sampel yang dipilih berdasarkan kebutuhan dan pertimbangan tertentu dari peneliti. Selain itu dilakukan juga pengamatan terhadap kegiatan-kegiatan yang dilaksanakan serta keadaan sekolah secara umum. Pengumpulan data dilakukan dengan metode observasi, partisipan, wawancara, dan dokumentasi. Keabsahan data dilakukan dengan teknik triangulasi, ketekunan, dan diskusi dengan teman sejawat. Analisis data yang digunakan adalah analisis interaktif terdiri dari tiga alur yaitu reduksi data, penyajian data, dan penarikan kesimpulan.

\section{HASIL DAN PEMBAHASAN}

\section{Karakter Kerja Kelautan dan Perikanan yang Ditanamkan}

Karakter kerja yang ingin ditanamkan di sekolah ini diantaranya adalah adalah disiplin, jujur, jiwa korsa, berani, mandiri, tanggung jawab, pantang menyerah, kerja sama, kerja keras, saling menghormati, semangat juang yang tinggi, jiwa kepemimpinan, jiwa patriotis, bermoral dan berakhlak mulia, suka menolong, bijaksana, ulet, toleransi, cekatan, cepat tanggap, patuh, mampu bersosialisasi, kompak, ikhlas, percaya diri, solidaritas, kompetitif, tangguh.

\section{Upaya Penanaman Karakter Kerja Kelautan dan Perikanan}

Upaya-upaya penanaman karakter kerja kelautan dan perikanan di SMKN 1 Sanden yang dilaksanakan diantaranya adalah melalui cara inkulkasi, pembiasaan, keteladanan, dan fasilitasi. Cara-cara tersebut dituangkan dalam berbagai kegiatan baik dalam intrakurikuler, kokurikuler, ekstrakurikuler.

Kegiatan ekstrakurikuler difasilitasi oleh sekolah dengan cara membentuk Tim Penggerak Pendidikan Karakter dan Budaya Bangsa. Tim ini membuat semacam program kerja yang dilaksanakan dalam satu tahun. kegiatan-kegiatan ekstrakurikuler seperti Apel dan pengibaran bendera, MOS/MP3K, LDDK (jurit malam dan pembaretan), BST, pramuka Saka Bahari, praktikum dan prakerin, beladiri, renang, dayung, BTA, baris-berbaris, iptek, prapada, olahraga/latihan fisik (lari, angkat barbell, full up, dan lain-lain) layanan konseling (BK), pentas seni, bersih pantai dan pelepasan tukik, penanaman pohon, pesantren ramadhan, dan lomba-lomba. Wahana juga bisa melalui cara berpakaian serta melalui peraturan dan sanksi.

\section{Pengintegrasian Karakter Kerja dalam Pembelajaran (Intrakurikuler)}

Integrasi penanaman karakter kerja kelautan dan perikanan dalam pembelajaran dilakukan dalam semua mata pelajaran terutama pada pelajaran produktif penanaman tersebut dapat secara intens dilakukan. Ketika guru masuk, para siswa disiapkan oleh ketua kelas masing-masing, terkadang diselingi dengan berjabat dan mencium tangan guru. Kemudian ketua kelas memberikan laporan kepada guru tentang kesiapan mereka sekaligus melaporkan kehadiran teman-temannya. Kemudian ketua kelas memimpin doa bersama, setelah itu seluruh kelas menyapa guru dengan ucapan selamat pagi atau selamat siang. Apabila prosesi tersebut telah dilaksanakan, pelajaran dapat dimulai. Diselasela penjelasan yang diberikan para guru biasanya menyelipkan nilai-nilai karakter yang harus dimiliki oleh siswa.

\section{Kegiatan kokurikuler}

Kegiatan kokurikuler adalah kegiatankegiatan yang bertujuan untuk menambah penguasaan siswa terhadap pelajaran atau penguasaan siswa terhadap kompetensi. Kegiatan kokurikuler di SMKN 1 Sanden meliputi Praktik Kerja Industri (Prakerin), praktikum, Basic Safety Training (BST), K3SAR (Penyelamatan di dalam air), Uji Kompetensi Siswa dan Prapada.

\section{Tata tertib dan Sanksi-Sanksi}

Semua peraturan yang tertulis pada tata tertib serta sanksi-sanksi yang diatur berkaitan erat dengan penanaman karakter kerja yang dilaksanakan. Selain hukuman-hukuman yang telah ditetapkan, untuk peraturan di kelas biasanya guru dan siswa melakukan berbagai kesepakatan-kesepakatan. Sanksi atau hukuman biasanya berkaitan erat dengan kegiatan fisik yang mereka lakukan sehari-hari misalnya push up, sit-up, scoot-jump, lari, jalan 
jongkok, push up berantai, merayap, dan lainlain. Hukuman juga bisa diberikan dalam bentuk ibadah misalnya shalat Dhuha atau bisa juga dalam bentuk kepedulian terhadap lingkungan seperti menyiram tanaman dan membersihkan lingkungan atau toilet.

\section{Pembiasaan dan Keteladanan}

Pembiasaan-pembiasaan yang dilakukan di sekolah ini adalah hormat, sapa, salam, dan salaman. Taruna dan taruni biasanya akan memberi hormat kepada para senior, guru, pamong, atau kepala sekolah dengan menyentuhkan ujung jari dipelipis kanan dengan posisi tubuh siap sambil mengucapkan selamat pagi atau selamat siang. Orang yang disapa akan membalas dengan ucapan selamat pagi atau selamat siang juga, dan sapaan bisa diselingi juga dengan salaman. Tradisi yang tetap dijaga sampai sekarang adalah para guru dan warga sekolah lain selalu saling bersalaman baik ketika datang maupun ketika akan pulang. Siswa juga selalu dibiasakan untuk selalu berbicara dalam bahasa Jawa yang halus atau kalau tidak bisa menerapkannya, siswa disarankan berbicara dalam bahasa Indonesia saja. Siswa sangat ditekankan untuk tidak mengeluarkan kata-kata kasar kepada siapapun. Pembiasaan lainnya adalah apabila para taruna menggunakan kendaraan ke sekolah maka mereka diwajibkan untuk menuntun kendaraannya ketika memasuki lingkungan sekolah sampai di area parker. Pembiasaan lainnya adalah selalu berpakaian rapi. Di sekolah ini telah ditetapkan ketentuan seragam yang harus dipakai taruna dan taruni dan sangat jelas tertulis dalam tata tertib.

\section{Fasilitasi}

Metode fasilitasi adalah dimana siswa dikenalkan dengan suatu nilai, kemudian sekolah memfasilitasi siswa untuk menerapkan nilai tersebut. Hal ini dilakukan siswa misalnya dengan membagi hewan qurban pada saat hari raya Idul Adha.

\section{Pihak-pihak yang Membantu Penanaman Karakter Kerja Kelautan dan Perikanan}

Pihak-pihak yang membantu penanaman karakter kerja kelautan dan perikanan ini sangat banyak, baik dari masyarakat, dunia usaha maupun dari instansi-instansi yang terkait. Dari instansi ada Pemerintah desa, kecamatan, kabupaten, dan provinsi, Dinas Pendidikan, DANLANAL, POLRI, Dinas Kelautan dan Perikanan, Dinas Perhubungan Laut, Dinas Kesehatan, Sekolah-sekolah Kelautan dan Perikanan atau Sekolah-sekolah Pelayaran, SAR Pantai, dan DU/DI (Dunia usaha/Dunia Industri).

\section{Hambatan-hambatan dan Faktor Pendukung Penanaman Karakter Kerja Kelautan dan Perikanan}

Filosofi "mangan ora mangan sing penting kumpul" sangat melekat pada masyarakat sekitar. Jadi ketika anak meminta ijin kepada orang tuanya untuk bekerja dikapal banyak yang tidak diijinkan dan hal ini sangat menghambat kemajuan karir sang anak nantinya. Untuk itu pihak sekolah biasanya melakukan sosialisasi dan propaganda tentang lapangan pekerjaan kelautan dan perikanan kepada orang tua siswa. Hambatan lainnya adalah kesadaran siswa, dukungan guru, personil pamong, dan fasilitas yang masih kurang.

Faktor pendukung penanaman karakter kerja kelautan dan perikanan di SMKN 1 Sanden adalah sumber daya manusia yang mendukung yaitu para taruna yang tangguh, guru-guru yang kompeten, perangkat sekolah yang mendukung serta pamong yang selalu eksis dalam pembinaan, dan yang tidak kalah penting adalah pihak-pihak luar yang selalu memberikan bantuan, pembinaan, serta dukungan moril. Hambatan yang dihadapi yaitu adanya perbedaan budaya orangtua yang mayoritas berlatar belakang petani sehingga masih sulit menerima konsep-konsep kelautan. Hambatan lainnya adalah masih adanya guru-guru yang kurang mendukung penanaman karakter kerja ini seperti kurangnya kedisiplinan atau kadang terjadi ketidakkonsistenan penanganan para siswa sehingga dapat menjadi contoh yang kurang baik. Fasilitas yang belum lengkap juga kadang menjadi kendala dalam penanaman karakter kerja ini. Cara mengatasi hambatan-hambatan tersebut diantaranya yaitu dengan mengadakan sosialisasi dan propaganda tentang lapangan pekerjaan di dunia kelautan dan perikanan kepada para orang tua siswa, kemudian memberikan pengertian-pengertian kepada guru-guru yang masih belum disiplin. Untuk fasilitas yang belum lengkap, pihak 
sekolah telah meminta bantuan kepada pemerintah daerah dan tinggal menunggu keputusannya.

\section{Evaluasi dan Monitoring Penanaman Karakter Kerja Kelautan dan Perikanan}

Evaluasi pendidikan karakter dilakukan dengan cara pengamatan terhadap sikap dan tingkah laku siswa, untuk nilai karakter secara umum biasanya diakumulasi dengan nilai Agama dan PKn pada akhir semester. Kemudian ada juga evaluasi pada semester akhir dikelas XII, nilai pengamatan tersebut akan diakumulasi menjadi nilai SIKAP dalam nilai akhir para siswa.

Penilaian karakter kerja kelautan dan perikanan telah tertanam pada diri siswa dapat dilihat dari ketertarikan siswa pada saat melakukan praktik, ketika para siswa diberikan satu trip pelayaran kemudian meminta tambahan trip lagi berarti pada diri siswa telah tertanam kecintaannya kepada dunia kelautan dan perikanan. Ketertarikan siswa juga dapat dilihat dari para alumni yang bekerja di kapal selalu berusaha meningkatkan jenjang karir mereka dengan mengikuti berbagai diklat.

\section{Tanggapan dan Perkembangan Siswa terhadap Penanaman Karakter Kerja Kelautan dan Perikanan}

Tanggapan siswa terhadap penanaman karakter kerja kelautan dan perikanan yang dilaksanakan di SMKN 1 Sanden sangat positif. Mereka merasa beruntung dan bangga telah bersekolah di sini. Menurut para siswa tidak semua anak mampu bersekolah di sini yaitu dengan kapasitas kedisiplinan yang tinggi. Perkembangan yang mereka rasakan pun sangat berbeda, yang dulunya masih membawa sifat dari SMP yang masih kekanak-kanakan dan kurang disiplin, setelah dididik mereka berubah menjadi lebih santun, hormat, tangguh, percaya diri, bertanggung jawab, dan yang pasti lebih disiplin.

\section{Tingkat Keberhasilan Penanaman Karakter Kerja Kelautan dan Perikanan}

Pada dasarnya penanaman karakter kerja kelautan dan perikanan di SMKN 1 Sanden telah mencapai titik keberhasilan. Walaupun tidak seratus persen, tetapi telah mampu menghasilkan tenaga kerja yang kompeten dan berkarakter. Daya serap dunia kerja terhadap lulusan sekolah ini sangat tinggi bahkan sampai ke luar negeri. Negara Jepang dan Taiwan sangat menyukai tarunataruni binaan SMKN 1 Sanden yaitu terlihat dari jumlah permintaan tenaga kerja yang semakin tahun semakin meningkat.

\section{Rencana Strategis Penanaman Karakter Kerja Kelautan dan Perikanan}

Rencana strategis yang akan dilakukan untuk meningkatkan penanaman karakter kerja kelautan dan perikanan diantaranya adalah pembangunan beberapa sarana dan prasarana seperti asrama, laboratorium, kolam renang, terminal penghubung dan tempat ibadah. Selain itu diusahakan pula untuk dapat memiliki kapal latih sendiri. Kemudian menjalin kerjasama dengan penyelenggara diklat ANKAPIN, ANTD, BST, penerbitan buku pelaut, ANKAPIN dan ANTD agar bisa menyelenggarakannya sendiri. Sertifikat ANKAPIN dipergunakan untuk ahli kapal penangkap ikan dan ANTD dipergunakan untuk ahli kapal dagang. Rencana strategis lain yaitu membawa para siswa untuk studi banding ke tempat-tempat yang berhubungan dengan dunia kelautan dan perikanan seperti ke Badan Meteorologi dan Oseanografi, pelabuhanpelabuhan, sekolah-sekolah kelautan, dan lain-lain. Kemudian frekuensi praktik dengan nelayan ditambah, untuk menambah pengalaman dan keahlian siswa. Selanjutnya dilakukan juga peningkatan pembinaan moral dan mental, optimalisasi tugas guru termasuk penambahan tenaga pengajar serta memberikan penyadaran kepada warga sekolah yang kurang mendukung. Dalam waktu dekat juga rencananya akan diadakan temu alumni untuk memperkaya wawasan para peserta didik sekaligus sebagai sarana evaluasi.

\section{SIMPULAN DAN SARAN}

Berdasarkan hasil penelitian dapat diambil beberapa simpulan sebagai berikut:

1. Konsep penanaman karakter kerja yang ditanamkan di SMKN 1 Sanden adalah memperbaiki kebiasaan siswa yang kurang baik dan membiasakan yang baik. Kebiasaan baik ini meliputi pembentukan 
karakter kerja yang berhubungan dengan kelautan dan perikanan.

2. Implementasi penanaman karakter kerja kelautan dan perikanan dilakukan dalam bentuk inkulkasi, pembiasaan, keteladanan, dan fasilitasi. Inkulkasi dilaksanakan dalam berbagai kegiatan intrakurikuler (integrasi dalam pembelajaran), kokurikuler (kegiatan pendukung pemahaman pembelajaran) dan ekstrakurikuler (kegiatan di luar jam sekolah), sedangkan pembiasaan dilakukan dengan cara salam sapa hormat dan izin, berdoa sebelum dan sesudah kegiatan, penghormatan sebelum dan sesudah pembelajaran, cara berpakaian, ujian/ulangan yg ketat, menuntun kendaraan ketika masuk lingkungan sekolah. Keteladanan ditunjukkan oleh para guru dan warga sekolah lain dengan hormat kepada yang lebih tua, berbahasa yang halus dan sopan, berjabat tangan, dan memberikan perhatian. Fasilitasi dilakukan dengan cara sekolah memfasilitasi kegiatan-kegiatan yang bertujuan untuk menerapkan sebuah nilai seperti pembagian hewan qurban dan konservasi lingkungan.

3. Karakter kerja yang ditanamkan di SMKN 1 Sanden diantaranya adalah disiplin, jujur, jiwa korsa, berani, mandiri, tanggung jawab, pantang menyerah, kerja sama, kerja keras, saling menghormati, semangat juang yang tinggi, jiwa kepemimpinan, jiwa patriotis, bermoral dan berakhlak mulia, suka menolong, bijaksana, ulet, toleransi, cekatan, cepat tanggap, patuh, mampu bersosialisasi, kompak, ikhlas, percaya diri, solidaritas, kompetitif, tangguh.

4. Wahana penanaman karakter kerja kelautan dan perikanan yaitu dalam kegiatankegiatan ekstrakurikuler seperti Apel dan pengibaran bendera, MOS/MP3K, LDDK (jurit malam dan pembaretan), BST, pramuka Saka Bahari, praktikum dan prakerin, beladiri, renang, dayung, BTA, baris-berbaris, iptek, prapada, olahraga/ latihan fisik (lari, angkat barbell, full up, dan lain-lain) layanan konseling (BK), pentas seni, bersih pantai dan pelepasan tukik, penanaman pohon, pesantren ramadhan, dan lomba-lomba. Wahana juga bisa melalui cara berpakaian serta melalui peraturan dan sanksi.
5. Integrasi penanaman karakter kerja kelautan dan perikanan dalam pembelajaran (intrakurikuler) dilaksanakan pada semua mata pembelajaran terutama pada pelajaran produktif. Pada saat pembelajaran ditanamkan nilai-nilai karakter kepada siswa. Guru juga selalu mengingatkan dan menekankan sikap-sikap yang harus dimiliki anak sewaktu bekerja.

6. Pihak-pihak yang sangat berperan dalam penanaman karakter kerja kelautan dan perikanan di SMKN 1 Sanden adalah selain warga sekolah sendiri juga dari TNI AL, Dinas Kelautan dan Perikanan, POLRI, SAR pantai, Dinas Kesehatan, Dinas Perhubungan Laut, Dinas Pendidikan, Kampus-kampus Kelautan dan Perikanan, DU/DI, Pramuka, pemerintah desa dan kecamatan serta kabupaten dan provinsi, orangtua/wali siswa, masyarakat, nelayan.

7. Bentuk evaluasi penanaman karakter kerja kelautan dan perikanan dilakukan dengan cara melakukan pengamatan terhadap sikap siswa dan mengakumulasinya sebagai nilai SIKAP pada akhir pembelajaran, evaluasi proses penanaman karakternya secara umum dilakukan dengan mencari informasi dari para alumni yang telah bekerja sekaligus meminta masukan guna peningkatan penanaman karakter kerja kelautan dan perikanan di SMKN 1 Sanden. Sedangkan monitoring dilakukan oleh seluruh perangkat sekolah seperti kepala sekolah, wakasek, wali kelas, guru, BK, pamong, dan staf dengan cara pengamatan secara langsung atau bisa juga dengan melihat dari hasil nilai akhir.

8. Faktor-faktor pendukung penanaman karakter kerja ini adalah sumber daya manusia yang sangat berpotensi untuk dibina dan saling mendukung dalam pelaksanaannya, adanya MOU (kesepakatan) dengan banyak pihak, dan adanya bantuan pihak luar. Faktor penghambat pelaksanaannya yaitu latar belakang orangtua (petani) kurang memahami tentang pekerjaan pelaut serta kesadaran siswa, dukungan guru, personil pamong, dan fasilitas yang masih kurang.

9. Tanggapan siswa dalam penanaman karakter kerja kelautan dan perikanan ini pada umumnya sangat antusias, walaupun 
terkadang ada yang suka melanggar peraturan, akan tetapi mereka pada akhirnya akan menyadari pentingnya pembinaan yang dilaksanakan disekolah ini untuk persiapan mereka dalam memasuki dunia kerja nantinya.

10.Penanaman karakter kerja kelautan dan perikanan dikatakan telah cukup berhasil dalam membekali para taruna karakterkarakter yang diperlukan dalam dunia kerja terbukti dari daya serap dunia kerja terhadap lulusan cukup besar. Salah satu indikator yang dapat dilihat terutama pada peningkatan jumlah permintaan tenaga kerja dari perusahaan kapal ikan luar negeri dan tidak ada keluhan yang disampaikan bahkan justru kebanyakan memperpanjang kontrak kerja.

11.Rencana strategis yang akan dilakukan untuk meningkatkan penanaman karakter kerja kelautan dan perikanan diantaranya adalah pembangunan beberapa sarana dan prasarana seperti tempat ibadah, laboratorium, asrama, perpustakaan, kolam renang, terminal penghubung antargedung, gedung olahraga, ruang yang lebih khusus untuk praktik. Selain itu diusahakan pula untuk dapat memiliki kapal latih sendiri. Kemudian menjalin kerjasama dengan penyelenggara diklat ANKAPIN, ANTD, BST, penerbitan buku pelaut, ANKAPIN dan ANTD agar bisa menyelenggarakannya sendiri. Sertifikat ANKAPIN dipergunakan untuk ahli kapal penangkap ikan dan ANTD dipergunakan untuk ahli kapal dagang. Rencana strategis lain yaitu membawa para siswa untuk studi banding ketempat-tempat yang berhubungan dengan dunia kelautan dan perikanan seperti ke Badan Meteorologi dan Oseanografi, pelabuhan-pelabuhan, sekolah-sekolah kelautan, dan lain-lain. Kemudian frekuensi praktik dengan nelayan ditambah, untuk menambah pengalaman dan keahlian siswa. Selanjutnya dilakukan juga peningkatan pembinaan moral dan mental, optimalisasi tugas guru termasuk penambahan tenaga pengajar serta memberikan penyadaran kepada warga sekolah yang kurang mendukung. Dalam waktu dekat juga rencananya akan diadakan temu alumni untuk memperkaya wawasan para peserta didik sekaligus sebagai sarana evaluasi.

\section{DAFTAR PUSTAKA}

Almusanna. (2010). Revitalisasi kurikulum muatan local untuk pendidikan karakter melalui evaluasi responsif. Jurnal pendidikan dan kebudayaan. Jakarta: Balitbang Kementerian Pendidikan Nasional Vol. 16 edisi khusus III, Oktober 2010.

Bohlin E. Karen. (2005). Teaching character education through literature. London and New York: 159

Character Education Partnership. (2012). Character Education. Journal of Character Education Partnership. Diakses tanggal 10 oktober 2012 dari http:// www.freedomforum.org/publications/fi rst/findingcommonground/B13.Charact erEd.pdf

Depdagri. (2009). Undang-undang no. 45 tahun 2009. www.depdagri.go.id/.../2009/.../undang-undang-no-45-tahun2009 -

Dharma Kesuma, Cepi Triatna, Johar Permana. (2011). Pendidikan karakter. Kajian teori dan praktik disekolah. Bandung: Remaja Rosdakarya.

Doni Koesoema. (2007). Pendidikan karakter. Jakarta: Grasindo. 162 hal.

Goleman, D. (2001). Kecerdasan Emosional (Terjemahan Hermaya, T). Jakarta: Gramedia Pustaka Utama.

Ridloudin Ahmad. (2009). Kepala badan pengembangan SDM kelautan perikanan membuka secara resmi diklat kepemimpinan tingkat III angkatan IV tahun 2009 di BDA sukamandi. Diakses pada tanggal 12 desember 2011 dari www.kkp.go.id/.../kepala-badanpengembangan-sdm-kelautan-perikanan-membuka-secara-resmi-dik...

Slamet P.H. (2011). Implementasi pendidikan karakter kerja dalam pendidikan kejuruan: Pendidikan karakter dalam persfektif teori dan praktik dalam Darmiyati Zuchdi (Editor). Pendidikan karakter dalam perspektif teori dan praktik. Yogyakarta: UNY Press.

Sumaryanto. (2011). Dimensi aksiologis dalam olahraga: relevansinya dalam pem- 
bentukan karakter. Cakrawala Pendidikan. Jurnal Ilmiah Pendidikan. Yogyakarta: LPM UNY Edisi Mei 2011, Th.XXX, Edisi khusus Dies Natalis UNY.

Suwarno. (2012). Di dunia kerja karakter lebih utama ketimbang entrepreneur. www.umk.ac.id/index.php?...di-duniakerja-karakter-lebih-utama-ket.. (Diakses tanggal 12 Desember 2012).

Undang-undang no. 20 Tahun 2003. Diakses pada tanggal 5 oktober 2011 dari www.slideshare.net/.../uu-no-20-tahun2003 - Amerika Serikat - 